\title{
Physiotherapy in the Prevention of Falls in Elderly People
}

\section{Atuação da Fisioterapia na Prevenção de Quedas em Idosos}

\author{
Jefferson Iago de Arruda e Souza ${ }^{\mathrm{a}}$; Maristela Prado e Silva Nazario*b; Olyvia Ribeiro Derze ${ }^{\mathrm{b}}$; \\ Juliana Santi Sagin Pinto Bergamim ${ }^{\mathrm{b}}$, Ariane Hidalgo Mansano Pletsch ${ }^{\mathrm{b}}$; Aline Ferrari ${ }^{\mathrm{b}}$
}

aUniversity of Cuiabá, Physiotherapy Course. MT, Brazil. ${ }^{\mathrm{b} C u i a b a ́}$ Institute of Education and Culture, Physiotherapy Course. MT, Brazil.

*E-mail: maristelaprado@hotmail.com

Recebido em: 14/05/19

Aprovado em: 26/07/19

\begin{abstract}
Brazil has around 14 million elderly and, in a certain area of the big cities, this population already exceeds the mark of $20 \%$. As the person ages the risk of falls increases. One in every three people above 65 years of age suffer from some type of fall at least once a year. The objective of this study was to identify the aging factor in humanity, the risk factors in falling in the elderly and consider information about the physiotherapy role in the senior patients treatment who suffer with injuries caused by falls. A bibliographic survey was held with the use of databases of the virtual library SciELO, Pubmed and Redalic from 2007 to 2017. Among the changes resulting from aging, the ones that generate postural instability are the locomotor, sensory and nervous changes, limiting the coordination and control of postural balance, called intrinsic factors. In this sense, physical therapy has been acting in the prevention, promotion, maintenance, and rehabilitation of pathologies affecting the elderly, extending the functional independence of this group. Based on these definitions it was possible to pinpoint prospects for the health performance in the mitigation of the effects of this event, as well as reduce the high hospital expenditures of the elderly to the public health.
\end{abstract}

Keywords: Physiotherapy. Aging. Accidents caused by Falls. Elderly.

\section{Resumo}

O Brasil tem cerca de 14 milhões de idosos e, em determinada área das grandes cidades, esta população já ultrapassa a marca dos 20\%. À medida que a pessoa envelhece o risco de quedas aumenta. Uma em cada três pessoas acima de 65 anos de idade sofrem algum tipo de queda pelo menos uma vez por ano. O objetivo desse estudo foi identificar o fator de envelhecimento na humanidade, os fatores de risco na queda em idosos e considerar informações sobre o papel desempenhado da fisioterapia no tratamento de pacientes sênior que sofrem com lesões causadas por quedas. Realizou-se um levantamento bibliográfico com a utilização dos bancos de dados da biblioteca virtual SciELO, Pubmed e Redalic de 2007 a 2017. Dentre as alterações decorrentes do envelhecimento, as que mais geram instabilidade postural são as alterações no aparelho locomotor, sensorial e nervoso, limitando a coordenação e o controle do equilibrio postural, chamados de fatores intrínsecos. Nesse sentido, a fisioterapia vem atuando na prevenção, promoção, manutenção e reabilitação de patologias que acometem o idoso, prolongando a independência funcional deste grupo. Com base nessas definições foi possivel apontar perspectivas para a atuação da saúde na mitigação dos efeitos deste evento, bem como reduzir o alto gasto hospitalar destes idosos para a saúde pública.

Palavras-chave: Fisioterapia. Envelhecimento. Acidente por Quedas. Idoso.

\section{Introduction}

Population aging is a worldwide phenomenon. The World Health Organization (WHO) predicts for 2025 the elderly population of 1.2 billion individuals. In Brazil, in 1960 the number of elderly individuals surpassed 3 million, in 1975 reached 7 million, in 2002 reached 14 million and it is estimated that in 2020 will reach 32 million ${ }^{1}$.

The transformation of the health care system in Brazil has been guided by a set of principles, such as the universalization of decentralization, integrality and popular participation. These principles were part of the initial agenda of the sanitary reform movement, being incorporated into the Constitution of 1988. After 21 years of implementation of the Unified Health System (SUS) practical evidences emerge of the efforts of thousands of managers, professionals and users of services in realizing these principles in everyday life of health services. The principle of comprehensiveness stands in the field of health practices, by the creative capacity of these actors in the effective exercise of SUS as policy and health services.

Fall is the most frequent type of accident in the elderly and its complications. Of the main causes of death in people over 65 years, occupies the third place as a cause of mortality among the elderly. Around 29\% of the elderly in Brazil fall at least once a year and $13 \%$ of them fall on a recurring basis ${ }^{2}$.

In an attempt to reduce the costs with medical assistance and improve the elderly quality of life, it is important that the knowledge on risk factors associated with hospital admissions among the elderly, in order to prevent the occurrence of these factors and also organize hospital services, outpatient clinics and in the community ${ }^{3}$. 
The objective of this study was to identify the aging factor in humanity, the risk factors in falling in the elderly and consider information about the physiotherapy role in the senior patients treatment who suffer with injuries caused by falls, in addition to the advance obtained in each physiotherapy procedure.

\section{Development}

\subsection{Methodology}

A bibliographic survey was held with the use of databases of the virtual library SciELO, Pubmed and Redalic from 2007 to 2017. On these bases, articles were identified on the performance and the effectiveness of a physiotherapist in the cure of diseases caused by falls in the elderly.

\subsection{Aging}

Since the beginning of the civilizations humanity is concerned with the aging process, but only in the early 20th century Elie Metchnikoff, successor of Pasteur, advocated the creation of a new specialty, the gerontology, title obtained from the expressions: gero (old age) and ology (study), marking the importance of the study of old age $\mathrm{a}^{4,5}$.

In recent years, several population groups had an increase in life expectancy, experiencing a change in the demographic profile and on morbidity and mortality, which resulted in an aging population, consequently a proportional increase of chronic degenerative diseases ${ }^{4.6}$.

Aging, before considered a phenomenon today is part of most companies reality. The world is aging. This is so true that it is estimated for the year 2050, that there are around two billion people with 60 years or more in the world, the majority living in developing countries. In Brazil, it is estimated that there are currently approximately 17.6 million elderly ${ }^{7}$.

The aging process is characterized by molecular and cellular changes that result in physiological changes, causing progressive functional loss of components, and the organism as a whole. This change does not involve all the functions at the same level and not at the same time ${ }^{8}$.

It is very common in aging progressive changes in the body occur, making it more susceptible to intrinsic or extrinsic damages. An example, within this susceptibility is the fall, which may be related to postural instability and sensory and motor systems alterations ${ }^{9}$.

There is not a consensus in relation to the beginning of aging, however, approximately at the age of 25 years, we can already observe a decline in body composition. There is a deterioration in the various systems and with the advancement of age, the skills of postural control are modified, generating postural instability and gait abnormalities, in addition to the bradykinesia, paresis and early fatigue, and may lead the elderly to serious functional limitations, which consequently will interfere in their quality of life ${ }^{8}$.

According to the National Health Policy in the elderly, comparing the beneficial aging to the elderly individual conservation in his or her family grounds and with their stable functional capacity, an elaboration of a program that stimulates the awareness of society and of the elderly individuals that work measures to reduce the risk of falls is urgent ${ }^{10}$.

In this context, prevention is necessary in order to minimize physical, social and psychological sequelae of falls, fostering the adequacy of health services, as well as for the professionals involved in the multidisciplinary care for these people. Therefore, the need for studies directed to this theme is realized with the aim to reduce the incidence of falls and their consequences and offer the audience a basic knowledge of guidance on risk factors for falls in household environments ${ }^{11}$.

The most susceptible elderly to falls are those that present some illness, especially those that lead the changes in mobility, balance and postural control, being the occurrence of falls directly proportional to the degree of functional disability ${ }^{12}$.

The therapeutic exercises in the water (hydrotherapy) have an important role in the prevention, maintenance and improvement of the elderly functionality. Water provides support and minimizes the biomechanical stress on the muscles and joints. Other benefits associated with aquatic exercises in hot water, are the improvement of blood circulation, increased muscle strength, increase the range of motion, muscular relaxation, temporary decrease of the level of pain, improved confidence and functional capacity ${ }^{13}$.

In this direction, it is observed that the falls are important causes of morbidity among the elderly and can have disastrous consequences. In addition to the risk of fractures, there is a loss of confidence to walk, due to fear of further falls, making the elderly decrease their mobility, forming a vicious circle, because with the restriction of activities there is a decrease in muscle strength, weakening of limbs, leading to a condition of dependence and social isolation ${ }^{14}$.

The population increase in life expectancy is a reality among the various population groups. This reality has determined a change in the demographic profile and morbidity and mortality rates, resulting in an aging population and consequent increase in proportion of chronic-degenerative diseases ${ }^{15}$.

The demographic projections indicate that in 2020 the number of elderly people throughout the world will be 1.2 billion. These same projections indicate that in 2025, Brazil will have the 6th largest elderly population of the world with 31.8 million individuals aged 60 or older ${ }^{16}$.

With the sharp increase in the number of elderly people, there is a need to understand the changes that make the body more susceptible to fall, which is determined by the capacity limitation of coordination and the body balance control. The changes in the nervous systems: (a decrease in the number of neurons, the speed of nervous conduction and reaction 
time), sensory (decrease in visual acuity, auditory and tactile sensitivity) and the locomotive apparatus (reduction of bone and muscle mass, muscle strength, increase of stiffness), are the main physiological changes that can lead the individual to fall ${ }^{17}$.

Fall can be defined as "an unintentional event that has as a result the individual change of position to a lower level in relation to his or her initial position." It often occurs as a sum of intrinsic and extrinsic risk factors, being difficult to restrict an event of fall to a single risk factor or a causal agent ${ }^{10.18}$.

The intrinsic factors are related to physiological changes, and the extrinsic to the environmental conditions. The incidence of falls is from $28 \%$ to $35 \%$ in elderly patients with more than 65 years of age, $35 \%$ of those with more than 70 years and $32 \%$ to $42 \%$ above 75 years ${ }^{10.18}$.

The episodes of falls involving the elderly have consequences that are not only by the health and social issues, but also reflected on the economic aspect, affecting physically and psychologically the individual. In France, according to data from the National Institute of Health and Medical Research (INSERM), 11 thousand people died as a result of an accidental fall, being that for every 10 people hospitalized for short periods, four fall, and among those stay for a very long time hospitalized, for every two, one will fall at least once a year ${ }^{11}$.

The CNS (central nervous system) plays a vital role so that the body adaptation and the balance maintenance occur. According to Guimarães and Farinatti (2009), problems of dynamic equilibrium have been considered as etiological factor for falls in the elderly, where approximately $50 \%$ of falls occur during some form of locomotion ${ }^{19}$.

Early rehabilitation in the context of the geriatrics aims at the prevention of diseases common to the third age, with the aim to mitigate and prevent the functional limitation of the elderly from progressing and resulting in fall. Fall can be defined as an imbalance episode that leads an individual to the ground, or it can be conceptualized as a sudden deficit of postural control. To prevent falls and the morbidities associated to the same, the physiotherapist can carry out activities of anteroposterior weight transfer, latero- lateral, gait on a treadmill of balance and circuits with obstacles ${ }^{20}$.

The following situations stand out: unsafe or risk environments which have low lighting, rugs scattered around the middle of the path, slippery and polished floors, toilets, very short sofas and chairs, as well as extra too short or high beds and poorly adapted shoes ${ }^{21}$.

The chronic bodily pains chronicles are a barrier commonly reported by the elderly people for not adopting the practice of physical exercise on a regular basis, and that the practice of regular physical activity decreases the body pain ${ }^{21}$.

In most cases when older people involve themselves in falls, there is some consequence which ends up significantly compromising the quality of life, being quite common that older people after undergoing some major fall become increasingly fearful that new episodes will occur. They even restrict to the minimum their trips outside the residence, however, the problem remains, because he or she knows that it is quite significant the number of this type of accident at home ${ }^{18}$.

The consequences of falls for the elderly are numerous, since biological changes to important fractures, interfering with the individual's psychosocial, daily activities, among others. Commonly, greater attention has been given to physical injury caused by falls, since these are dangerous, which may even lead to death if not treated. These losses are also associated to hospitalizations and treatments that demand a high financial cost to the families ${ }^{22}$.

Prevention is important in order to minimize secondary problems resulting from falls. Studies have shown that it is possible to reduce the occurrence of falls with simple care as: a) health promotion and the prevention of falls;

b) Review of medications; c) modifications in households; d) safety promotion at home; e) safety promotion outside the household. Multidisciplinary interventions can help in the fall prevention process in the population ${ }^{6}$.

The physiotherapist is one of health professionals essential in the actions for a better quality of life and health of the elderly, taking as goals preserve motor function, prevent disability resulting from the aging process, deal with the alterations and the symptoms originated from diseases, within their specialties, and may act in the falls prevention ${ }^{23}$.

The physiotherapist has, in his or her major social current function, extensive participation in the population health, both for the prevention of falls in the elderly and in their treatment after fall, promoting health ${ }^{23}$.

\subsection{Risk factors for falls in the elderly}

Defined by the researchers as "an unintentional event that results in a change of the individual from his or her current level to a lower level without correction possibility". Possibly a fall is related to the temporary or permanent sudden failure in one of the systems responsible for postural maintenance or even complete loss of balance caused by an external factor. In geriatrics, the fall is treated as a geriatric syndrome due to having multifactorial and heterogeneous involvement ${ }^{24}$.

Hospitalization is recognized as a risk factor for functional decline of older people, which may lead to loss of independence and autonomy, and exacerbate one already existing, functional impairment due to excessive rest, sleep deprivation, polypharmacy, immobility, mental confusion, depression, hospital infection, malnutrition and inadequate use of physical restraint in bed ${ }^{25}$.

In this direction, it is observed that the falls are important causes of morbidity among the elderly and can have disastrous consequences. In addition to the risk of fractures, there is a loss of confidence to walk, due to fear of further falls, making the elderly decrease their mobility, forming a vicious circle, because with the restriction of activities there is a decrease in 
muscle strength, weakening of limbs, leading to a condition of dependence and social isolation ${ }^{26}$.

It is recorded that motor coordination and concentration are directly influenced by the cognitive, reflecting the difficulty performing two or more tasks simultaneously - for example, talk and walk, which predisposes to falls. According to MS1, physical and social performance of the elderly depends on the integrity of their cognitive functions ${ }^{27}$.

For the elderly, falling is not a simple event, many factors are involved in its occurrence and consequences. Due to having a more fragile body, upon falling even from their own height, the individual may present fractures, lesions on the skin, bruises, besides being psychologically affected by that event, depending on its severity and/or psychological condition, the elderly at the time of the fall can develop depression, fear of falling, isolation, difficulty of socialization, among others. The hospitalizations and institutionalizations are frequent realities in the elderly post-fall ${ }^{28}$.

According to MS1, the majority of the accidental falls occurs inside their houses or in its surroundings, usually during the performance of daily activities such as walking, changing position and going to the bathroom. The influence of environmental factors on the risk of falls is associated with functional status and mobility of the elderly person. The more fragile the elderly, the more susceptible to falls ${ }^{26}$.

Luzio et al. ${ }^{27}$ claim that only found a higher prevalence of environmental risks present in the house of elders who fell when they presented cognitive deficit, attributing it to the fact that environmental risks alone would not be strong enough to lead the elderly to fall.

They also report that the elderly intrinsic characteristics, added to several environmental factors that exceed their physical-functional capacity, would result in the event of falling. Postural maneuvers and environmental barriers that are not problems for the healthier elderly may, however, become a serious threat to the security and mobility of those with alterations in balance and gait ${ }^{27}$.

Fall can be defined as an imbalance episode that leads an individual to the ground, or it can be conceptualized as a sudden deficit of postural control. To prevent falls and the morbidities associated to the same, the physiotherapist can carry out activities of anteroposterior weight transfer, latero- lateral, gait on a treadmill of balance and circuits with obstacles $^{20}$.

In advanced age, there is a high incidence of diseases such as cataracts, glaucoma and diabetic retinopathy, which can compromise the ability to judge an imminent fall and proceed with corrective action. The interpretation of the spatial information may be compromised by a deficit in visual acuity, restriction of the visual field, increased susceptibility to light, deficient depth perception or instability in fixing the gaze ${ }^{29}$.

Different from the intrinsic factors that can be altered, they require a body treatment that can take in some cases several months or years, the extrinsic factors are in turn of rapid change, not taking more than a few weeks to their alteration ${ }^{2}$.

Among the major factors, we can mention the following ones $^{30}$ :

Stairs without a handrail; little space between furniture; Supports instability; slippery floor; Objects and toys scattered; low lighting; Rugs without anti-slip coating; beds, chairs, toilets in irregular height; deregulated gait devices. Very steep ramps; uneven floors; absence of informational notices on irregular floors.

Parker $^{31}$ also says that headache is often associated with visual disturbances, nausea and vomiting. Dizziness can result in a disorder that can affect the balance and lead to a fall.

In assessing the home environment, the following were identified as more frequent risks of falls: absence of bar in the bathroom, presence of carpets, presence of rungs, nonslip mat $\mathrm{w}$ in the bathroom and difficult access to the light switch. A few safety devices were found in the bathroom, as, for example, support rails, despite having been found elderly with disabilities and needs of these safety devices ${ }^{26}$.

Studies have indicated that the falls are the fifth leading cause of death for people with more than 65 years and which represent $2 / 3$ of these accidental deaths. In the study by Fabricio et al. ${ }^{24}$ was found that in the USA approximately $70 \%$ of falls in the elderly are fatal, and this index increases with people over 80 years of age ${ }^{24}$. Perracini and Ramos ${ }^{2}$ state that the elderly individuals aged over 80 years are 14 times more likely to fall (exposing themselves to risks of injuries and fractures resulting from falls) than the elderly with inferior age.

The relationship between medication use and falls has been extensively investigated in the literature. Studies show that although it is not possible to report the cause, the use of drugs increases the risk of falls, especially in more fragile elderly patients or who use more severe drugs. In another study an association was found between the need to use medication of continuous use and the occurrence of falls ${ }^{32}$.

\subsection{Preventive physiotherapy}

The prevention of falls is a matter of importance in public health due to losses and related morbidity. Primary prevention is possible in some circumstances. However, in general terms, primary prevention has not been fully effective. However, measures such as physical activity, nutrition, risk assessment and periodic review of medications are essential for the prevention of falls $8,33,34$.

The physical activities should be carried out regularly, aiming postural stability and balance that both influence in gait. These can be prevented with strengthening of upper limbs and trunk, joint mobilization, gait training with obstacles and/ or uneven soils, changes in decubitus (sitting to standing and vice-versa, lifting from the ground, lying down to sitting), agility exercises, in addition to aerobic and proprioceptive activity ${ }^{34,35}$.

According to Meale et al. ${ }^{36}$ hydrotherapy can be used in 
the falls prevention together with walking in the pool, muscle strengthening and stretching exercises and activities for training postural balance.

The prevention should also be made by guidance to patients and families in relation to possible changes in the elderly environment. It is necessary to remove or fix rugs on the floor; do not leave telephone and television wires, for example, exposed; wear comfortable shoes with non-slip sole; store frequently used objects at hand; if there are stairs, adapt handrails; Install light switch next to the bed, have a flashlight on the nightstand during the night; always keep a glass of water next to the bed as well as emergency phone numbers; installing support bars in the bathroom and nonslip mats in the shower; avoid obstacles at home such as a center table; do not leave shoes or toys scattered on the floor of the house; examine the backyard for holes, upon getting up wait a while sitting to standing, avoiding dizziness ${ }^{8,37}$.

In the study by Resende et al. ${ }^{38}$ carried out with 50 elderly people over 60 years, with independent gait, independence in AVD and no medical contraindication to exercise, upon being submitted to a program of hydro kinesiotherapy during 12 weeks, with sessions of 40 minutes, one can observe that the hydro kinesiotherapy program promoted an increase in the balance and a concomitant decrease in the risk of falls, agreeing with other studies published.

Exercises help people to maintain greater possible force to the extent that the aging process occurs. When performing exercises, it is possible and expected to increase the quality of life, reduce the risk of falls and maintain or improve function in several activities. In line with the theme, Sachetti ${ }^{20}$, reaffirms that in addition to balance the chronic pain impairs the functionality in the aging process and in their study was unable to demonstrate that the long-lived elderly women physically inactive have chronic pains that hinder the practice of regular physical activity, in concordance with the data in the literature that suggest that $35 \%$ of the Brazilian population that have chronic pain, $75 \%$ believed that this affects the daily life activities, considering that the pain is limiting for the physical activities.

The chronic bodily pains chronicles are a barrier commonly reported by the elderly people for not adopting the practice of physical exercise on a regular basis, and that the practice of regular physical activity decreases the body pain ${ }^{15}$.

The practice of physical activities provides pain reduction through the release of endorphins, responsible for increasing tolerance to pain. Therefore, it is of utmost importance that the elderly people engage in some type of physical activity and practice it on a regular basis ${ }^{39}$.

The episodes of falls involving the elderly have consequences that are not only by the health and social issues, but also reflected on the economic aspect, affecting physically and psychologically the individual. In France, according to data from the National Institute of Health and Medical
Research (INSERM), 11 thousand people died as a result of an accidental fall, being that for every 10 people hospitalized for short periods, four fall, and among those stay for a very long time hospitalized, for every two, one will fall at least once a year ${ }^{11}$.

In 2010, Lustosa et al. $^{40}$ carried out a program of functional exercises for senior citizens in a community and noted that there was an improvement in the balance of these elderly patients after training. The program was composed of a warm-up phase and then passed to the functional training that consisted of exercises in plantar flexion gait, dorsiflexion, stay in alternation of unipodal support, lateral gait, gait with increased hip flexion and tandem gait. These activities had progression with the use of hands objects, like small cones. Circuits training was used, in which the participants should circumvent cones and hula hoops, walking on mats, climbing up and down stairs of various sizes and heights; and, still, exercises of the upper extremities with balls and sticks, reaching activities, trunk extension and rotation exercises in small amplitudes, sitting down and standing up from the chair. The cooling phase consisted in the stretching of the major muscle groups of the lower limbs.

Pereira et al. $^{41}$ carried out a Tai Chi program with the objective of verifying their effects on balance and in the strength of the knee extensor muscles in elderly women. He developed the work in 12 weeks, with a frequency of three weekly practices, being 50 minutes duration each lesson. And observed that after the end of the program, the women participants obtained an improvement in muscular strength and balance.

In order to operationalize the inclusion of professionals as a physical educator, social worker, psychologist, physiotherapist, occupational therapist, speech therapist, nutritionist and medical specialists in the ESF the Ordinance No 154 was instituted of 24th of January 2008, of the Ministry of Health, which creates the Support Centers to Family Health - NASF, which strengthens the FHS. This calls for the coordination of care from Basic Care ${ }^{42}$.

NASF allows the implementation of actions aimed at the promotion, protection and recovery of health and ensures the principles of universality, comprehensiveness and equity. They expand the breadth and scope of the actions of primary care, as well as its resolvability, supporting the insertion of ESF in the services network and the territorialization and regionalization process of the basic attention ${ }^{42}$.

The higher susceptibility of elderly people to suffer falls is due to the functional decline resulting from the aging process, determined by the increase of the time, the reaction and decrease the efficiency of motor strategies of body balance. Imbalance is one of the main factors that confine the life of the elderly ${ }^{11}$.

The term quality of life is quite complex, as no consensual definition is found about its real meaning ${ }^{43}$. Quality of life is 
influenced by determinants and conditions of health-disease process, being that economic and sociocultural aspects associated to knowledge, experiences and values of individuals and collective interfere in the way to be interpreted ${ }^{44}$.

According to the WHO, quality of life is the individual's perception of their position in life in the context of culture and system of values in which he or she lives, considering their goals, expectations, standards and concerns ${ }^{45}$.

In Brazil, the quality of life theme came to have meaning and importance in research in the health area in the last decade, more precisely from 1992, when the average number of publications has increased seven times compared with the 10 first raised years (1982 to 1991$)^{46}$.

The quality of life can be assessed by specific or generic instruments. The specific instruments can be engineered for the disease, function or problem, these being more sensitive and responsive to their purpose. The generic tools can compare the quality of life among individuals with different chronic diseases or to assess the disease impacts in a population, however, by the fact of being global, they are not very indicated to specific diseases ${ }^{47}$.

\section{Conclusion}

With the increase in life expectancy, there is a concern to contribute to the quality of life of the elderly population, preventing chronic non-communicable diseases, in spite of progressive limitations that may occur. To do so, it is necessary that more studies be developed on the person, producing health indicators so that they can plan multiprofessional actions, by establishing networks, revealing the peculiarities of this population, as well as risks that predispose to falls, because they raise the rates of morbidity in the elderly.

It is very important that health professionals who work directly with the elderly public know the theme "fall" in this population. Since the interventions and preventive care indicate an association of factors related to several aspects, such as drug control, health education, exercises and physical activities, accessibility, maintenance of functional capacity, among others, it is thus concluded that, to achieve the ideal point of control falls, it is necessary that the elderly receive multiprofessional support.

Therefore, it is up to the professionals of the area to look at this scenario, each acting on their particularities, and all collaborating for the best life condition of the elderly individuals.

\section{References}

1. Lima-Costa MF, Veras R. Saúde pública e envelhecimento. Cad Saúde Pública 2007;19(3):15-21. doi: http://dx.doi. org/10.1590/S0102-311X2003000300001

2. Perracini MR, Ramos LR. Fatores associados a quedas em uma coorte de idosos residentes na comunidade. Rev Saúde Pública 2002;36(6):709-16. doi: http://dx.doi.org/10.1590/ S0034-89102002000700008.
3. Berg K, Wood-Dauphine S, Gayton WD. Measuring balance in the elderly: preliminary development of an instrument. Physiother Can 1989;41(6):304-11. doi: https://doi. org/10.3138/ptc.41.6.304.

4. Thomaz E, Papaléo M, Maria Y. Biologia e teorias do envelhecimento. In: Tomaz E, Papaléo M. Geriatria: fundamento, clínica e terapêutica. São Paulo: Atheneu; 2006. p.3-18.

5. Papaléo M. O estudo da velhice no século XX: história, definição do campo e Termos Básicos. In: Viara E, Py L, Neri A, Xavier F, Garzoni M; Rocha S. Tratado de geriatria e gerontologia. Rio de Janeiro: Guanabara Koogan; 2002. p.212.

6. Siqueira AB, Cordeiro RC, Perracini MR, Ramos LR. Impacto funcional da internação hospitalar de pacientes idosos. Rev Saúde Pública 2004;38(5):687-94. doi: http://dx.doi. org/10.1590/S0034-89102004000500011.

7. Brasil. Ministério da Saúde. Envelhecimento e saúde da pessoa idosa. Cad. Atenção Básica, n.19, 2006.

8. Freitas EV, Cançado FAX, Doll J, Gorzoni ML. Tratado de geriatria e gerontologia. Rio de Janeiro: Guanabara Koogan; 2013.

9. Guimarães, LHCT, Galdino DCA, Martins FLM, Vitorino DFM, Pereira KL, Carvalho EM. Comparação da propensão de quedas entre idosos que praticam atividade física e os idosos sedentários. Rev Neurocs 2004;12(2):68-72.

10. Ribeiro PP, Souza ER, Atie S, Souza AC, Schilithz AO. A influência das quedas na qualidade de vida de idosos. Ciênc Saúde Coletiva 2008;13(4):1265-73. doi: http://dx.doi. org/10.1590/S1413-81232008000400023.

11. Alves Júnior ED, Paula FL. A prevenção de quedas sob o aspecto da promoção da saúde. Fit Perf J 2008;7(2):123-9. doi: 10.3900/fpj.7.2.123.p

12. Barbosa MT. Como avaliar quedas em idosos. Rev Assoc Med Bras 2001;47(2):85-109. doi: http://dx.doi.org/10.1590/ S0104-42302001000200012

13. Gabilan YPL, Perracini MR, Munhoz MSL, Ganança FF. Fisioterapia aquática para reabilitação vestibular. Acta ORL 2006. 25-30.

14. Yuaso DR, Sguizzatto GT. Fisioterapia em pacientes idosos. In: Papaléo Netto M. Gerontologia: a velhice e o envelhecimento em visão globalizada. São Paulo: Atheneu; 1999.

15. Piccini RX, Facchini LA, Tomasi E, Thumé E, Silveira DS, Siqueira FV, et al. Necessidades de saúde comuns aos idosos: efetividade na oferta e utilização em atenção básica à saúde. Ciênc Saúde Coletiva 2006;11(3):657-667. http:// dx.doi.org/10.1590/S1413-81232006000300014.

16. Gazzola JM, Ganança FF, Perracini MR, Aratani MC, Dorigueto RS, Gomes CMC. O envelhecimento e o sistema vestibular. Fisioterapia em Movimento 2005; 18(3):39-48.

17. Sanglard RC, Pereira JS. A influência do isostretching nas alterações dos parâmetros da marcha em idosos. Fisioterapia Brasil 2005; 6(4): 255-256.

18. Pinho L, Dias RC, Souza TR, Freire MTF, Tavares CF, Dias JMD. Avaliação isocinética da função muscular do quadril e tornozelo em idosos que sofrem quedas. Rev Bras Fisiotera 2005;9(1): 93-9.

19. Soares MA, Sacchelli T. Efeitos da cinesioterapia no equilíbrio de idosos. Rev Neurocienc 2008;6(2):97-100.

20. Sachetti A, Vidmar MBF, Silveira MM, Wibelinger LM. 
Equilíbrio x Envelhecimento humano: um desafio para a fisioterapia. Rev Ciênc Méd Biol 2012;11(1):64-9.

21. Maciel A. Quedas em idosos: um problema de saúde pública desconhecido pela comunidade e negligenciado por muitos profissionais da saúde e por autoridades sanitárias brasileiras. Rev Med Minas Gerais 2010;20(4):554-7.

22. Menezes RL, Bachion MM. Estudo da presença de fatores de riscos intrínsecos para quedas, em idosos institucionalizados. Ciênc. Saúde Coletiva 2008;13(4):1209-18. doi: http:// dx.doi.org/10.1590/S1413-81232008000400017.

23. Carmo M, Jacob W. Idoso no cento de terapia Intensiva. In: Viara E, Py L, Neri A, Xavier F, Garzoni M, Rocha S. Tratado de geriatria e gerontologia. Rio de Janeiro: Guanabara Koogan; 2002. p.740- 743.

24. Fabricio SCC, Rodrigues RAP, Costa Junior ML. Quedas acidentais em idosos institucionalizados. Acta Paul Enferm 2002;15(3):51-9.

25. Oliveira HML, Rodrigues LF, Caruso MFB, Freire NSA. Fisioterapia na prevenção de quedas em idosos: revisão de literatura. Rev Interdisc Estudos Experimentais 2017;9:43-7.

26. Piovesan AC, Pivetta HMF, Peixoto JMB. Fatores que predispõem a quedas em idosos residentes na região oeste de Santa Maria, RS. Rev. Bras. Geriatr. Gerontol 2011;14(1):75-83. doi: http://dx.doi.org/10.1590/S1809-98232011000100009.

27. Luzio CS, Garcia FV, Benzinho T, Veiga VG. Programa de prevenção de quedas no idoso. Porto: Porto; 2003.

28. Hamra A, Ribeiro MB, Miguel OF. Correlação entre fratura por queda em idosos e uso prévio de medicamentos. Acta Ortop Bras 2007;15(3):143-5. doi: http://dx.doi.org/10.1590/ S1413-78522007000300004.

29. Rozenfeld S. Reações Adversas aos medicamentos na terceira idade: as quedas como iatrogenia farmacoterapêutica. Rio de Janeiro. Universidade do Estado do Rio de Janeiro; 1997.

30. Almeida ST, Soldera CLC, Carli GA, Gomes I, Resende TL. Análise de fatores extrínsecos e intrínsecos que predispõem a quedas em idosos. Rev Assoc Med Bras 2012;58(4):427-33.

31. Parker S. O livro do corpo humano. São Paulo: Ciranda Cultural; 2007.

32. Dall JO, Van Lieshout JJ. Falls and medications in the elderly. Neth J Med 2005;63(3):91-6.

33. Papaléo Netto M. Gerontologia. São Paulo: Atheneu; 2002.

34. Cunha MF, Lazareschi L, Gantus MC, Suman MR, Silva A, Parizi CC, et al. A influência da fisioterapia na prevenção de quedas em idosos na comunidade: estudo comparativo. Motriz Rev Educ Fis 2009;15(3):527-36.

35. Pickles B, Compton A, Cott C, Simpson J, Vandervoort A.
Fisioterapia na terceira idade. São Paulo: Santos; 2000.

36. Bruni BM, Granado FB, Prado RA. Avaliação do equilíbrio postural em idosos praticantes de hidroterapia em grupo. Mundo Saúde 2008;32(1):56-63.

37. Paes EM, Vera L, Gaspar V. As injúrias não intencionais no ambiente domiciliar: a casa segura. J Pediatr 2005;81:S146S154.

38. Resende SM, Rassi CM, Viana FP. Efeitos da hidroterapia na recuperação do equilíbrio e prevenção de quedas em idosas. Rev Bras Fisioter 2008;12(1):57-63.

39. Gomes GAO, Cintra FA, Diogo MJD, Neri AL, Guariento ME, Sousa MLR. Comparação entre idosos que sofreram quedas segundo desempenho físico e número de ocorrências. Rev Bras Fisioter 2009;13(5):430-7.

40. Lustosa LP, Oliveira LA, Santos LS, Guedes RC, Parentoni AN, Pereira LSM. Efeito de um programa de treinamento funcional no equilíbrio postural de idosas da comunidade. Fisioter Pesq 2010;17(2):153-6.

41. Pereira MM, Oliveira RJ, Silva MAF, Souza LHR, Vianna LG. Efeitos do Tai Chi Chuan na força dos músculos extensores dos joelhos e no equilíbrio em idosas. Rev Bras Fisioter 2008;12(2):121-6.

42. Brasil. Ministério da Saúde. Portaria no 154. Cria os Núcleos de Apoio a Saúde da Família - NASF. Brasília: MS; 2008.

43. Spitzer WO. State of Science 1986: quality of life and functional status as target variables for research. J Chronic Dism1987;40(6):465-71.

44. Seidl E MF, Zannon CMLC. Qualidade de vida e saúde: aspectos conceituais e metodológicos. Cad Saúde Pública 2004;20:580-8.

45. Fleck MPA, Fachel O, Louzada S. Desenvolvimento da versão em português do instrumento de avaliação de qualidade de vida da Organização Mundial de Saúde (WHOQOL -100). Rev Bras Psiquiatr 1999;21(1):19-28.

46. Paschoal S. Qualidade de vida do idoso: elaboração de um instrumento que privilegia a sua opinião. São Paulo: USP; 2000.

47. Guyatt GH, Naylor CD, Juniper E, Heyland DK, Jaeschke R, Cook DJ. Users' guides to the medical literature. XII. How to use articles about health-related quality of life. EvidenceBased Medicine Working Group. JAMA 1997;277(15):12327. 